$7-2007$

\title{
Economic War and Democratic Peace
}

Cullen F. Goenner

University of North Dakota, cgoenner@business.und.edu

How does access to this work benefit you? Let us know!

Follow this and additional works at: https://commons.und.edu/ef-fac

Part of the Economics Commons

\section{Recommended Citation}

Cullen F. Goenner. "Economic War and Democratic Peace" (2007). Economics \& Finance Faculty Publications. 12.

https://commons.und.edu/ef-fac/12

This Article is brought to you for free and open access by the Department of Economics \& Finance at UND Scholarly Commons. It has been accepted for inclusion in Economics \& Finance Faculty Publications by an authorized administrator of UND Scholarly Commons. For more information, please contact und.commons@library.und.edu. 


\title{
Economic War and Democratic Peace
}

\author{
Cullen F. Goenner* \\ Department of Economics \\ University of North Dakota \\ Grand Forks, ND 58202 \\ cullen.goenner@und.edu \\ 701-777-3353
}

June 23, 2006

*Acknowledgements

I would like to thank Steven Durlauf, Glenn Palmer, Jon Pevehouse, and several anonymous referees for helpful comments and suggestions on earlier versions of this paper. The data used in this paper can be obtained from

http://www.business.und.edu/goenner/research/data.htm . 


\title{
Economic War and Democratic Peace
}

\begin{abstract}
Research has shown that democracies rarely if ever engage each other in war and are less likely to have militarized disputes than when interacting with authoritarian regimes. Economic sanctions are an alternative to militarized conflict viewed by the masses as more acceptable. The conflict-inhibiting effects of democratic norms and institutions are thus weakened with respect to the use of sanctions. This paper examines whether a country's decision to initiate sanctions is influenced by its regime type as well as that of the potential target. The results indicate for the period 1950-1990 that the more democratic a country is the more likely it is to initiate sanctions. Democracies, though, are less likely to target other democratic regimes relative to non-democratic regimes. With respect to sanctions use, pairs of democracies are not peaceful.
\end{abstract}

KEY WORDS: economic sanctions, democratic peace, trade interdependence.

JEL CODES: D74; F51; H56

\section{Introduction}

Immanuel Kant envisioned that a world of democracies would be characterized by peace. Democratic governments, unlike their authoritarian counterparts, he argued, promote peace as they allow the citizenry that face the burdens of war to directly influence the decision to go to war. Today Kant's legacy lives on as policymakers and researchers alike recognize the relation of democracy and peace. This notion of a democratic peace is that norms and institutions of democratic regimes, when paired with other democratic regimes, form shared values of friendship and compromise, which promote nonviolent interactions. Support for this is based on the historical absence of wars between democratic countries (Babst, 1972; Small \& Singer, 1976) and the results of numerous empirical studies (Goenner, 2004; Oneal, Oneal, Maoz, \& Russett, 1996; Oneal \& Russett, 1997, 1999a) that find democratic pairs of states are less likely to engage in militarized disputes than are other pairs. This has led some (Levy, 1988) to 
describe the empirical version of the proposition as the closest thing in international relations to a law.

A recent question of interest is whether this law like relation extends to forms of international relations other than militarized conflict. Farber and Gowa (1997) for instance have found that democratic pairs of countries are more likely to be allies. Democracies are also more likely to share membership in non-governmental organizations (Russett, Oneal, \& Davis, 1998), vote more similarly in the United Nations (Oneal \& Russett, 1999b), have more open trade policy (Mansfield, Milner, \& Rosendorff, 2000), and trade more (Morrow, Siverson, \& Tabares, 1998).

Busch (2000) and Reinhardt (2000), though, challenges the notion that democracy contributes to positive economic interactions. Reinhardt's (2000) analysis of the initiation of GATT disputes finds that democratic pairs of states participate in more trade disputes and are less likely than other pairs of countries to resolve them cooperatively. Similarly, Busch (2000) finds that pairs of democracies are more likely to escalate trade disputes and are less likely to settle their disputes by offering concessions. These findings suggest that democracies, while never at war, may substitute economic for militarized forms of conflict.

The purpose of this paper is to examine the monadic and dyadic relationships between political regime type and the initiation of economic sanctions during the period 1950-1990. Analyzing directed dyads, we find that democratic regime type is related to sanctions use in a complex way. The monadic results indicate that increasing the level of democracy increases the probability that a country initiates sanctions. Democracies though are significantly more likely to target non-democratic regimes than they are other 
democracies. Despite this finding, democratic pairs of countries are not peaceful with respect to the use of sanctions as they are more likely to use sanctions than authoritarian pairs of countries.

\section{Sanctions and the Democratic Peace}

The economic sanctions cases examined here were collected by Hufbauer, Schott, and Elliott (1990, p.2) and include sanctions that were used to achieve foreign policy goals. Cases are described as "the deliberate, government inspired withdrawal, or threat of withdrawal, of customary trade or financial resources," where foreign policy goals "encompass changes expressly and purportedly sought by the sender state in the political behavior of the target state." The typical foreign policy goals for using sanctions are to obtain a change in policy, destabilize, or impair the military potential of the targeted country. Examples used for these purposes include sanctions initiated by the US against Britain and France seeking their withdrawal from the Suez, sanctions imposed by the US against Nicaragua to destabilize the Sandinista government, and sanctions imposed by NATO countries on several Eastern Bloc countries to prevent the proliferation of strategic technology.

Economic sanctions include both trade and financial controls. Trade sanctions are used to deny exports to the target and reduce imports from the target. The effects of their use will depend on the substitutability of the goods and markets in question. In cases where substitutes are not readily available for the target, such as sanctions imposed on Iraq after the first Gulf War, the effects can be devastating. Export controls tend to be used more frequently than import controls because an initiating country is more likely to be the dominant producer, rather than consumer of a good. The denial of strategic goods 
is also an important reason export controls are frequently imposed. Financial controls involve actions such as the denial of development aid, access to credit, and the freezing of assets. Of the 111 sanctions cases examined by Hufbauer, Schott, and Elliott (1990), 24 used trade controls alone, 32 financial controls alone, and 55 used both types.

To understand the use of sanctions one must realize that regimes maximize their wellbeing over a set of policy choices, which includes the use of diplomacy, economic sanctions, and war. ${ }^{2}$ Regimes considering the use of sanctions weigh the utility from initiating sanctions relative to alternatives. This indicates the possibility of foreign policy substitution (Most \& Starr, 1985), where factors that contribute to the use of sanctions in one setting may lead to war in another. While sanctions are often perceived as ineffective (Huffbauer, Schott, \& Elliott, 1990; Morgan \& Schwebach, 1997; Pape, 1997), their use may be dictated by the setting. Of particular concern in this paper is whether democracies, which are constrained in their use of war with each other, substitute economic for militarized forms of conflict.

The democratic peace proposition asserts that political regime type influences interaction among countries in a way such that the characteristics found in democracy foster peaceful interaction. ${ }^{3}$ Maoz and Russett (1993) consider the two most important of these characteristics to be democratic norms and institutions, where norms reflect common beliefs and institutions provide constraints by channeling interactions.

Norms are a typical behavior pattern and in the context of the democratic peace it is asserted that interactions which take place within a country influence how they interact with others. This relation Weart (1998) believes is part of the human need for consistency. Within democratic regimes, boycotts and strikes are two economic forms of 
conflict that are viewed as acceptable responses to transgressions. Boycotts, similar to import sanctions, involve the refusal to purchase a firm's goods or services and are used to obtain policy changes. A strike is similar in effect to export sanctions, as individuals refuse to sell their labor to firms. It is not surprising then that democratic countries in 1974 blocked attempts by the Soviet Union to expand the UN definition of aggression to include economic measures. Today, democratic norms view economic sanctions as a preferred means of dispute resolution. Perhaps over time this may change, similar to values that once accepted dueling as a means of settling disputes.

Institutions may work to constrain a country's decision to initiate sanctions. Democratic institutions provide the means for citizens to ensure that their chosen representatives carry out their wishes. ${ }^{4}$ Actions that are costly to citizens, such as war, generate significant public debate that constrains the ability of democratic leaders to act. Economic sanctions, unlike militarized acts, are easily reversible and take a great deal of multilateral coordination to have long term effects. The effects of sanctions at home and abroad are difficult to quantify as compared with militarized acts, which can produce images of destroyed homes and casualties on the nightly news. While trade sanctions do impose costs on domestic markets, the costs are most often borne by a small number of domestic firms competing in the export market in which controls are imposed. Democratic leaders thus face fewer institutional constraints in the use of economic relative to military force. This weakening of checks and balances is evident in the US, where the Export Administration Act of 1979 and its revisions authorize the President to initiate export sanctions on goods in order to promote US foreign policy objectives. 
Democratic norms, which support the use of economic sanctions to achieve foreign policy goals, combined with a lack of institutional checks, suggests that democratic countries are more likely to use sanctions than countries with mixed or authoritarian regimes, with all else equal. Despite their willingness and ability to use sanctions, democracies may be reluctant to initiate sanctions on other democracies, which share an affinity for compromise and the peaceful settlement of disputes. Dixon (1993, 1994) and Raymond (1994), for example, have shown that democracies are more likely than other countries to seek third party intermediation to settle disputes.

Use of an intermediary does not necessarily result in compromise. Busch (2000) finds trade disputes between democracies brought before GATT are more likely to escalate beyond the initial consultation stage to the formation of a formal panel. Further, conditioning on the formation of a panel, pairs of democracies are no more likely than other regime pairs to offer concessions, despite their willingness for third party adjudication before GATT. This behavior by democratic regimes, with regards to the use of sanctions, may be primarily a response to the public's demands to do something (Renwick, 1981; Nossal, 1989). Sanctions imposed under GATT are initiated solely at the request of domestic interest groups that seek enforcement of current trade agreements. Countries impose this type of sanction to appease domestic interests (Goldstein \& Martin, 2000; Haftel, 2004), knowing that such acts are unlikely to affect international relations. ${ }^{5}$ The type of sanctions examined here differs in this respect as they are driven more by international relations (Drezner, 1998, 1999; Drury, 2001) and a desire to coerce. ${ }^{6}$

Democracies may impose sanctions on each other without fear of further escalation or domestic unrest. Reducing the cost of sanctions, though, may make their 
use more likely. The stability-instability paradox is that stability among pairs of democracies, with respect to militarized conflict, could contribute to their increased use of economic sanctions. ${ }^{7}$ This reduction in costs also affects the ability of democratic regimes to credibly signal to each other their resolve using threats of economic sanctions. Fearon (1994) and Smith (1998) believe that leaders of democratic countries face higher audience costs, allowing them to rely more frequently on words rather than actions. Without audience costs, threats become little more than cheap talk. Constrained and unable to demonstrate resolve, pairs of democracies may find themselves more likely to use economic sanctions than other pairs of countries.

\section{Analysis of Economic Sanctions Initiation}

The empirical analysis examines sanctions episodes drawn from Hufbauer, Schott, and Elliott (1990), which provide 111 case studies of economic sanctions used for foreign policy goals throughout 1914-1990. Their case studies attempt to include all known instances of sanctions of this type, though the authors recognize that sanctions used between states of the second and third world may have been omitted. ${ }^{8}$ Each of the case studies indicate for our coding purposes the initiator(s) of sanctions and the corresponding target(s) along with the years in which sanctions were imposed.

The unit of observation is a directed dyad year, where the sample includes all directed pairings of countries for each year. ${ }^{9}$ Both directions are included, which implies that our dependent variable codes separately both whether the US initiated sanctions against Canada in a given year and whether Canada initiated sanctions against the US. The reason for the distinction is that sanctions episodes, unlike militarized actions, are typically one sided and do not involve retaliation. We examine the post world war period 
1950-1990 because it is during this period in which economic interactions are said to have increased in importance as part of international relations. 1990 is selected given it is the last year that sanctions data are available. The sample contains over 560,000 observations.

The analysis examines the onset of economic sanctions as well as their continued use. This allows one to determine whether there are differences in the factors that influence the initiation and the continuation of disputes (Beck, 2003; Beck, Katz, \& Tucker 1998; Oneal \& Russett, 1999a). "Onset" sets the first year that economic sanctions are initiated by a country against another equal to 1 and drops from the analysis all other observations of the same dispute. Multiple sanctions episodes are possible during a year, which results in an overlap of disputes. In such cases, the first year of the subsequent dispute is also included in the analysis as an onset of a dispute.

"Involvement" sets each year economic sanctions are used by one country against another equal to 1 .

The independent variables used in this analysis control for the willingness and ability of countries to engage in economic sanctions. Motivation influences whether conflict of a certain type is politically feasible, while capability constraints determine if action is physically feasible. Controls typical to the study of militarized conflict are used here to analyze economic conflict. Understanding the conditions that influence the use of force will help us to understand the use of economic sanctions. Data for the independent variables was obtained from the dataset used by Oneal (2003) to analyze militarized disputes. 
Regime type data are taken from the Polity III data set (Gurr, Jaggers, and Moore, 1990). A single measure for regime type is created by subtracting the autocracy score from the democracy score and adding 10, so the transformed measure ranges from pure autocracy $(0)$ to pure democracy $(+20)$. In our analysis we examine separately the effects that the regime types of the initiating country and target have on sanctions use. An interaction term, which is the product of each country's regime scores, is included to control for the effect of shared democratic characteristics.

Additional independent variables are included. Allies is a binary variable that takes the value 1 if the states in the dyad have formally agreed to a defense pact, neutrality pact, or entente as defined by the Correlates of War (COW) project. Formation of an alliance requires agreement on a common goal. Common interests increase the benefits of compromise, thereby promoting the peaceful settlement of disputes. These alliances though may not prevent the use of economic sanctions, as regimes constrained from war by an alliance may resort to their use. This may be particularly true given Hufbauer et al's (1990) finding that sanctions are generally more successful when allies are targeted. Thus we posit that regimes constrained from militarized conflict by alliances may be more likely to use economic sanctions.

Contiguity and distance capture the idea that conflicts of interest typically involve neighboring states. Contiguity is coded 1 if countries share a border or are separated by less than 150 miles by water either directly or via dependencies. We expect to find that countries are more likely to initiate sanctions against neighboring countries. Distance measures the great circle distance between country's capitals or in some cases ports. One would expect that increasing distance would reduce the opportunity for disputes to form 
between countries. The capability ratio has been used to measure a country's means to engage in military war and is the logarithm of the capability ratio of the larger to lower state. One would expect the larger the ratio, the less likely a dispute will escalate to the use of sanctions. Separate variables are included to control for whether the initiating or target countries are major powers. ${ }^{10}$ One expects these countries, which are active in global affairs, to be more likely to initiate as well as be targeted with sanctions.

Researchers are increasingly interested in the effects of trade on conflict between countries. ${ }^{11}$ Increasing a country's dependence on trade with another country is said by classical liberals to create economic and social ties that bind countries' interests and inhibit conflict. Gartzke and Li (2003) offer that economic integration improves a country's ability to send costly signals and demonstrate resolve during disputes. The idea is that threats to sever trade or impose sanctions frighten financial markets, producing significant economic costs to countries integrated into the world economy. Threats made by countries dependent on trade are thus more credible, reducing the need for action. Empirical analysis of MIDs by Gartzke and Li (2003), using alternative measures of economic integration, generally supports this notion. We expect that increasing a country's dependence on trade with another country reduces their likelihood of initiating sanctions.

A country's ability to effectively use economic sanctions as a policy tool depends on the targeted country's dependence on the initiating country for trade. Hufbauer et al. (1990, p. 99) find for the sanctions episodes they examine that the initiating country accounts for $28 \%$ of the target's trade in successes, compared to $19 \%$ in failures. In a game theoretic model, Crescenzi (2003) shows that increasing a country's economic ties 
increases their likelihood of being targeted with low level conflict, which includes the use of economic sanctions. ${ }^{12}$ Crescenzi also conducts logistic regression analysis of low level dyadic disputes controlling for the targeted country's import inelasticity and trade share along with an interaction term for the two controls. ${ }^{13}$ Increasing the inelasticity of import demand and trade share together significantly increase the likelihood of low level conflict.

Here we measure country i's dependence on country j's trade as the sum of the pair's bilateral exports and imports divided by country i's GDP. Data for bilateral exports and imports as well as GDP are from Gleditsch's (2002) expanded trade dataset. One expects country $i$, the potential initiator, to be less likely to impose sanctions against countries they are dependent on for trade. Additionally, one would expect that a country is more likely to be targeted with sanctions from a country they depend on for trade.

Finally we include in the analysis four variables that are designed to control for the duration dependence of observations. The idea is that the longer countries have interacted peacefully the less likely they will engage in conflict. Following the recommendation of Beck, Katz, and Tucker (1998) a natural cubic spline of the previous years of economic peace is formed with three knots, which generates the four peace year variables.

\section{Results}

To determine the effects that democratic norms and institutions have on the use of economic sanctions we estimate the following equation:

$$
\begin{aligned}
& \text { SANCTIONS }_{\mathrm{j}, t}=\beta_{0}+\beta_{1} \text { DEM }_{\mathrm{i}, t-1}+\beta_{2} \text { DEM }_{\mathrm{j}, t-1}+\beta_{3} \text { JNTDEM }_{\mathrm{i}, t-1-1}+\beta_{4} \text { ALLIES }_{\mathrm{j}, t-1}+\beta_{5} \operatorname{CONTIG~}_{\mathrm{ij}, t-1}+
\end{aligned}
$$

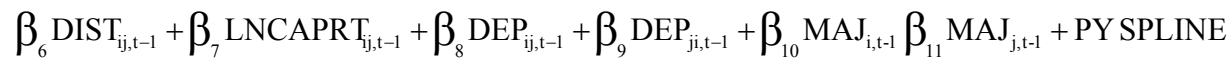


where country $\mathrm{i}$ represents the potential initiator and country $\mathrm{j}$ the potential target in each pair of countries. The independent variables, excluding the peace year variables, have all been lagged one year to avoid problems associated with regressors, such as trade at time $t$, which may be influenced by the dependent variable at time $t$. We examine both the initial onset and continued involvement of economic sanctions. Logistic regression is used to model the probability that sanctions are initiated or continued. Huber robust standard errors that cluster on each directed dyad are provided along with the coefficient estimates in Table 1.

[Insert Table 1 about here]

From the monadic perspective we examine whether democracies are empirically more likely than authoritarian and mixed regimes to initiate sanctions. The marginal effect of increasing a country's level of democracy on their initiating sanctions is measured by:

$$
\frac{\Delta \text { Sanctions }}{\Delta D E M_{i}}=\beta_{1}+\beta_{3} D E M_{j}
$$

The inclusion of the target's regime type in equation 3 is due to the measure of joint democracy, the product of the two countries' regime type scores. ${ }^{14}$ For the onset of sanctions, the value of equation 3 ranges from .0141 for fully democratic targets $\left(\mathrm{DEM}_{\mathrm{j}}=\right.$ 20) to .1161 for fully non-democratic targets $\left(\mathrm{DEM}_{\mathrm{j}}=0\right)$. The positive value throughout the entire range of regime values indicates that increasing a country's level of democracy increases their likelihood of initiating sanctions, unconditional of the regime type of their target. Similar calculations are made for the prolonged involvement of economic sanctions, where values range from -.0601 to .1379 for fully democratic and nondemocratic targets, respectively. The breakpoint at which the effect changes from 
negative to positive occurs at a regime type score of 14 . For our sample, the majority of countries $(65 \%)$ have regime scores less than 14 and on average equal 8.86 . The regime type characteristics of the interstate system thus suggest that the monadic effect of democracy on sanction's use is positive. The more democratic a country is the more likely they are to use sanctions.

Democracies, while prone to using sanctions, are found to be significantly more likely to use sanctions against non-democratic countries, relative to other democracies. The negative coefficients for $\beta_{3}$ in Table 1 , along with equation 3 , indicate that the marginal effect of increasing a country's level of democracy on their initiation and use of sanctions is reduced the more democratic the targeted country. Pairs of democracies though are not characterized as peaceful when it comes to the use of economic sanctions. Figure 1 provides a visual representation of the complex interaction between shared regime type and the onset and involvement of economic sanctions for a pair of countries with the mean level of characteristics. The figure indicates that democratic countries are more likely to initiate sanctions than non-democratic and mixed regimes and are particularly prone to initiate sanctions against non-democratic countries. With respect to sanctions involvement, the figure takes the shape of a saddle, where democratic and nondemocratic pairs of countries are less likely to use sanctions than democratic/nondemocratic or mixed pairs.

[Insert Figure 1 about here]

The quantitative effects can be further seen in Table 2, which provides for comparison the probability of sanctions use for various regime type pairs. The probability for each group is formed using the means of each of the variables, other than 
regime type, along with the logistic regression estimates. From these results one sees that a country that becomes fully democratic from the mean level $\left(\mathrm{DEM}_{\mathrm{i}}=10\right)$ increases the probability they initiate sanctions against a country with mean regime type $\left(\mathrm{DEM}_{\mathrm{j}}=10\right)$ by $(.000154-.00008) / .00008=93 \%$ compared to $(.00008-.000071) / .00008=13 \%$ for a fully democratic country. With respect to the prolonged involvement of economic sanctions, a country that becomes fully democratic from its mean level is $48 \%$ more likely to use sanctions against a country with a mean level of democracy, whereas it is $45 \%$ less likely to use sanctions against another democratic country. Overall, democratic pairs are 194\% more likely than non-democratic pairs and as likely as mixed pairs to suffer the onset of sanctions. For involvement, democratic pairs are $156 \%$ more likely than non-democratic pairs to be involved in the prolonged use of sanctions and are $40 \%$ less likely to use sanctions than mixed pairs.

\section{[Insert Table 2 about here]}

With respect to the other control variables the results of the analysis are largely what one would expect. Major powers are more likely to initiate and to be the target of economic sanctions. Increasing the military capability ratio was found to reduce the probability that sanctions are used. Perhaps somewhat surprising is the finding that alliance ties have a positive effect on the use of sanctions, which is statistically significant with regards to their onset. This likely reflects the idea that economic sanctions serve as an alternative means to send a message without the threat of breaking military ties. The effects of trade dependence are mostly found to be insignificant. For the onset of sanctions, the coefficient for the initiating country's dependence is positive, whereas for involvement the sign is negative, as predicted. The dependence of the target 
has a positive effect on both the onset and involvement of sanctions as predicted, but is only significant in the former sample. Distance and contiguity are the only two variables that vary significantly between sanctions onset and involvement. With respect to onset, the coefficient for contiguity is negative, while for distance it is positive and significant. These estimated effects are reversed when it comes to involvement in sanctions. Longstanding disputes that involve sanctions are more likely to be between contiguous countries and those separated by less distance.

\section{Conclusion}

In the post world war period the utility of militarized acts as an instrument of policy has diminished. This decline is due in large part to the increased destructiveness of militarized conflict (Knorr, 1966). Economic sanctions are an alternative, short of war, that countries can use to achieve foreign policy goals. While economic relations have historically been an important part of international relations, Baldwin (1985) finds little modern interest in the study of economic statecraft. Globalization though has led to renewed interest in economic interactions, such as US trade with China. Knowledge of the factors that contribute to the use of sanctions is important to understanding the future of international relations.

The empirical findings suggest that countries may substitute economic for militarized forms of conflict in disputes that begin far from home and those between allies. Alliance ties and distance both have a positive and statistically significant effect on the onset of sanctions, whereas these effects are negative with respect to militarized disputes (Oneal \& Russett, 1999a). The concern examined here is whether democratic norms and institutions, which inhibit militarized conflict, allow democracies to substitute 
the use of economic sanctions in their disputes. Democratic norms are more accepting of economic forms of conflict and as such fewer normative and institutional constraints are placed on the use of sanctions. The results indicate that democracies are significantly more likely to initiate sanctions than non-democratic countries. Despite their willingness to use sanctions, democracies are significantly more peaceful with each other than they are with non-democratic regimes. 


\section{NOTES}

${ }^{1}$ Hufbauer et al. (1990, p. 2) exclude cases in which positive incentives are used along with those involving foreign policy goals that are part of the "normal realm of economic objectives sought in banking, commercial, and tax negotiations."

${ }^{2}$ Baldwin (1985) believes these choices are considered in order by decisionmakers.

${ }^{3}$ Ray (1995) and Chan (1997) provide a detailed review of the democratic peace literature

${ }^{4}$ Seven institutions that Dahl (1989, p. 221) argues are necessary for the highest attainment of democracy are; 1) elected officials, 2) free and fair elections, 3) inclusive suffrage, 4) right to run for office, 5) freedom of expression, 6) alternative information, and 7) associational autonomy

${ }^{5}$ Commercial rivalry such as the "Cattle War" fought between the US and Canada in 1974 involved the United States applying counter tariffs in response to discriminatory tariffs from Canada.

${ }^{6}$ Drury (2001) argues that the lack of public attention paid to the use of sanctions and foreign policy more generally makes it unlikely that sanctions examined here are used as a means to placate domestic interests.

${ }^{7}$ The stability-instability paradox was originally applied by Snyder (1965) to nuclear deterrence. Mutually assured destruction implied that conventional war was unlikely to escalate to the nuclear level, reducing the cost of conventional war. The reduction in cost made conventional war more likely. I would like to thank an anonymous reviewer for this point.

${ }^{8}$ Analysis of pairs consisting of a major power did not reveal any significant difference.

${ }^{9}$ Oneal and Russett (1997) analysis of militarized disputes examines what they refer to as politically relevant dyads; pairs of states that are either contiguous or contain a major power. Given sanctions can be easily applied, near and far, we believe the larger sample to be more suitable. Analysis of politically relevant dyads did not qualitatively change the results reported.

${ }^{10}$ Singer and Small (1994) define the major powers as USA, China, USSR, UK, and France during the period examined, 1950-1990.

${ }^{11}$ Barbieri and Schneider (1999) and Mansfield and Pollins (2001) provide a review of the empirical literature. See Schneider, Barbieri, and Gleditsch (2003) and Mansfield and Pollins (2003) for a broader discussion. 
${ }^{12}$ Crescenzi's (2003) develops a two stage sequential game that models a country's decision to escalate beyond economic to militarized force. At each stage the challenger (initiating country) can choose to make a demand accompanied by a threat. The first stage threat includes low levels of conflict (denial of trade), while the second stage threat involves the use of militarized force. The target has the ability to accept or reject the demand and the challenger may back down. The payoffs to the model are such that increasing the target's dependence (exit cost) increases the likelihood of sanctions (low level conflict) and decrease the likelihood of militarized disputes (high level conflict).

${ }^{13}$ Dispute data are drawn from the World Events Interaction Survey. Data for import elasticity is only available for a small sample of countries.

${ }^{14}$ Greene (1997, pp. 391-392) provides a discussion of the interpretation of marginal effects in the presence of interaction terms. 


\section{REFERENCES}

Babst, D. V. 1972. A Force for Peace. Industrial Research 14: 55-58.

Baldwin, D. A. 1985. Economic Statecraft. Princeton: Princeton University Press.

Barbieri, K., and G. Schneider. 1999. Globalization and Peace: Assessing New Directions in the Study of Trade and Conflict. Journal of Peace Research 36: 463-479.

Beck, N. J. 2003. Modeling Dynamics in the Study of Conflict: A Comment on Oneal and Russett. In G. Schneider, K. Barbieri, N. P. Gleditsch (Eds.) Globalization and Armed Conflict. Lanham: Rowman and Littlefield.

Beck, N., J. N. Katz, and R. Tucker. 1998. Taking Time Seriously: Time-Series- CrossSection Analysis with a Binary Dependent Variable. American Journal of Political Science 42: 1260-1288.

Busch, M. L. 2000. Democracy, Consultation, and the Paneling of Disputes under GATT. Journal of Conflict Resolution 44: 425-446.

Chan, S. 1997. In Search of Democratic Peace. Mershon International Studies Review 41: 59-91.

Crescenzi, M. J. C. 2003. Economic Exit, Interdependence, and Conflict. The Journal of Politics 65: 809-832.

Dahl, R. 1989. Democracy and Its Critics. New Haven: Yale University Press.

Dixon, W. J. 1993. Democracy and the Management of International Conflict. Journal of Conflict Resolution 37: 42-68.

Dixon, W. J. 1994. Democracy and the Peaceful Settlement of International Conflict. American Political Science Review 88: 14-32.

Drezner, D. 1998. Conflict Expectations and the Paradox of Economic Coercion. International Studies Quarterly 42: 709-731.

Drezner, D. 1999. The Sanctions Paradox: Economic Statecraft and International Relations. Cambridge, UK: Cambridge University Press.

Drury, A. C. 2001. Sanctions as Coercive Diplomacy: The U.S. President's Decision to Initiate Economic Sanctions." Political Research Quarterly 54: 485-508.

Farber, H., and J. Gowa. 1997. Common Interests or Common Polities? Reinterpreting the Democratic Peace. Journal of Politics 59: 393-417. 
Fearon, J. D. 1994. Domestic Political Audiences and the Escalation of International Disputes. American Political Science Review 88: 577-592.

Gartzke, E., and Q. Li. 2003. War, Peace, and the Invisible Hand: Positive Political Externalities of Economic Globalization. International Studies Quarterly 47: 561-586.

Gleditsch, K. S. 2002. Expanded Trade and GDP. Journal of Conflict Resolution 46: $712-724$.

Goenner, C. F. 2004. Uncertainty of the Liberal Peace. Journal of Peace Research, 41: 589-605.

Goldstein, J., and L. L. Martin. 2000. Legalization, Trade Liberalization, and Domestic Politics: A Cautionary Note. International Organization 54: 603-632.

Greene, W. H. 1997. Econometric Analysis, $3^{\text {rd }}$ ed. Upper Saddle River, NJ: Prentice Hall.

Gurr, T. R., K. Jaggers, and W. H. Moore. 1990. The Transformation of the Western State: The Growth of Democracy, Autocracy, and State Power Since 1800. Studies in Comparative International Development 25: 73-108.

Haftel, Y. Z. 2004. From the Outside Looking In: The Effect of Trading Blocs on Trade Disputes in the GATT/WTO. International Studies Quarterly 48: 121-142.

Hufbauer, G. C., J. J. Schott, K. A. Elliott. 1990. Economic Sanctions Reconsidered: History and Current Policy. Washington, DC: Institute for International Economics.

Knorr, K. 1966. On the Uses of Military Power in the Nuclear Age. Princeton: Princeton University Press.

Levy, J. S. 1988. Domestic Politics and War. Journal of Interdisciplinary History.18: 653-677.

Mansfield, E. D., H. V. Milner, and B. P. Rosendorff. 2000. Why Democracies Cooperate More: Electoral Control and International Trade Agreements. International Organization 56: 477-513.

Mansfield, E. D., and B. M. Pollins. 2001. The Study of Interdependence and Conflict: Recent Advances, Open Questions, and Directions for Future Research. Journal of Conflict Resolution 45: 834-859. 
Mansfield, E. D., and B. M. Pollins, editors. 2003. Economic Interdependence and International Conflict: New Perspectives on an Enduring Debate. Ann Arbor: The University of Michigan Press.

Maoz, Z. and B. Russett. 1993. Normative and Structural Causes of Democratic Peace. American Political Science Review 87: 624-638.

Morgan, C. and V. Schwebach. 1997. Fools Suffer Gladly: The Use of Economic Sanctions in International Crises. International Studies Quarterly 41: 27-50.

Morrow, J., R. Siverson, and T. Tabares. 1998. The Political Determinants of International Trade: The Major Powers, 1907-1990. American Political Science Review 92: 649-662.

Most, B. A., and H. Starr. 1985. International Relations Theory, Foreign Policy Substitutability, and 'Nice' Laws. World Politics 36: 383-406.

Nossal, K. 1989. Economic Sanctions as International Punishment. International Organization 43: 301-322.

Oneal J. R. 2003. Measuring Interdependence and Its Pacific Benefits: A Reply to Gartzke \& Li Journal of Peace Research 40: 721-725.

Oneal, J. R., F. H. Oneal, Z. Maoz, and B. Russett. 1996. The Liberal Peace: Interdependence, Democracy, and International Conflict, 1950-1985. Journal of Peace Research 33: 11-28.

Oneal, J. R. and B. Russett. 1997. The Classical Liberals Were Right: Democracy, Interdependence, and Conflict, 1950-1985. International Studies Quarterly 41: 267-293.

Oneal, J. R. and B. Russett. 1999a. Assessing the Liberal Peace with Alternative Specifications: Trade Still Reduces Conflict. Journal of Peace Research 36: 423-442.

Oneal, J. R. and B. Russett. 1999b. Is the Liberal Peace Just an Artifact of Cold War Interests? Assessing Recent Critiques. International Interactions 25: 213-241.

Pape, R. 1997. Why Economic Sanctions Do Not Work. International Security, Vol. 22, pp. 90-136.

Ray, J. L. 1995. Democracy and International Politics: An Evaluation of the Democratic Peace Proposition. Columbia, SC: University of South Carolina Press. 
Raymond, G. A. 1994. Democracies, Disputes, and Third Party Intermediaries. Journal of Conflict Resolution 38: 24-42.

Reinhardt, E. 2000. Aggressive Multilateralism: The Determinants of GATT/WTO Dispute Initiation, 1948-1998. Unpublished manuscript, Emory University.

Renwick, R. 1981. Economic Sanctions. Rensselaer, NY: Hamilton Printing.

Russett, B., J. R. Oneal, and D. R. Davis. 1998. The Third Leg of the Kantian Tripod for Peace: International Organizations and Militarized Disputes, 1950-1985.

International Organization 52: 441-467.

Schneider, G., K. Barbieri, and N. P. Gleditsch, editors. 2003. Globalization and Armed Conflict. New York: Rowman and Littlefield.

Singer, J. D. and M. Small. 1994. Correlates of War Project: International and Civil War Data, 1816-1992. Study 9905. Ann Arbor, MI: Inter-University Consortium for Political and Social Research.

Small, M. and J. D. Singer. 1976. The War Proneness of Democratic Regimes. Jerusalem Journal of International Relations 1: 50-69.

Smith, A. 1998. International Crises and Domestic Politics. American Political Science Review 92: 623-638.

Snyder G. 1965. The Balance of Power and the Balance of Terror, in P. Seabury (Ed.) The Balance of Power. San Francisco, CA: Chandler.

Weart, S. R. 1998. Never at War: Why Democracies Will Not Fight One Another. New Haven: Yale University Press. 
Table 1: Logistic regression results from modeling the Onset and Involvement of Economic Sanctions 1950-1990

\begin{tabular}{lcccc}
\hline & \multicolumn{2}{c}{ Onset } & \multicolumn{2}{c}{ Involvement } \\
Independent Variables & Coefficient & $\begin{array}{c}\text { Robust } \\
\text { Std. Error }\end{array}$ & Coefficient & $\begin{array}{c}\text { Robust } \\
\text { Std. Error }\end{array}$ \\
\hline DEM(i) & $0.1193^{* *}$ & 0.0228 & $0.1379^{* *}$ & 0.0260 \\
DEM(j) & 0.0421 & 0.0299 & $0.1064^{* *}$ & 0.0314 \\
JNTDEM & $-0.0054^{*}$ & 0.0024 & $-0.0099^{* *}$ & 0.0022 \\
Allies & $1.0347^{* *}$ & 0.2430 & 0.0672 & 0.2759 \\
Contiguity & -0.4382 & 0.4125 & $0.9534^{* *}$ & 0.3550 \\
Distance & $0.3046^{*}$ & 0.1524 & $-0.5621^{* *}$ & 0.1324 \\
Capability Ratio & $-0.1692^{* *}$ & 0.0527 & $-0.2799^{* *}$ & 0.0580 \\
Dependence(i) & 0.0933 & 2.6339 & -33.1060 & 21.1453 \\
Dependence(j) & $1.5770^{*}$ & 0.7397 & 0.4939 & 1.5636 \\
Major Power(i) & $3.3609^{* *}$ & 0.2323 & $3.7327^{* *}$ & 0.2212 \\
Major Power(j) & $2.0085^{* *}$ & 0.4241 & $1.7952^{* *}$ & 0.3728 \\
Spline1 & -0.0020 & 0.0019 & $-0.0337^{* *}$ & 0.0028 \\
Spline2 & -0.0007 & 0.0015 & $0.0208^{* *}$ & 0.0019 \\
Spline3 & $0.0013^{*}$ & 0.0006 & $-0.0031^{* *}$ & 0.0006 \\
Peace Years & $-0.4152^{* *}$ & 0.1072 & $-2.398^{* *}$ & 0.1765 \\
Constant & $-11.0752^{* *}$ & 1.2508 & -0.3761 & 1.1018 \\
& & & & \\
Log likelihood & -1117 & & -3462 & \\
Pseudo R ${ }^{*}$ & 0.2162 & & 0.6103 & \\
$\mathrm{~N}$ & 561440 & & 562542 & \\
\hline *p $\leq .05, * * \mathrm{p} \leq .01$ & & & & \\
\hline
\end{tabular}


Table 2: Probability of the Onset and Involvement of Economic Sanctions by Political Regime Type, 1950-1990

\begin{tabular}{|c|c|c|c|}
\hline \multirow[t]{2}{*}{ Onset } & \multicolumn{3}{|c|}{$\mathrm{DEM}_{\mathrm{j}}$} \\
\hline & 0 & 10 & 20 \\
\hline 0 & 0.000027 & 0.000041 & 0.000063 \\
\hline $\mathrm{EM}_{\mathrm{i}} \quad 10$ & 0.000090 & 0.000080 & 0.000071 \\
\hline 20 & 0.000296 & 0.000154 & 0.000080 \\
\hline
\end{tabular}

\begin{tabular}{cc|ccc|}
\multicolumn{2}{l}{ Involvement } & \multicolumn{3}{c}{$\mathrm{DEM}_{\mathrm{j}}$} \\
& & 0 & 10 & 20 \\
\cline { 3 - 5 } $\mathrm{DEM}_{\mathrm{i}}$ & 10 & 0.000005 & 0.000014 & 0.000040 \\
& 20 & 0.000019 & 0.000020 & 0.000022 \\
\cline { 3 - 5 } & 0.000075 & 0.000030 & 0.000012 \\
\hline
\end{tabular}

Note: $\mathrm{DEM}_{\mathrm{i}}=$ regime type of initiating country

$\mathrm{DEM}_{\mathrm{j}}=$ regime type of target

Variables, other than JNTDEM, are evaluated at their means. 
Figure 1: The Onset and Involvement of Economic Sanctions by Political Regime Type, 1950-1990
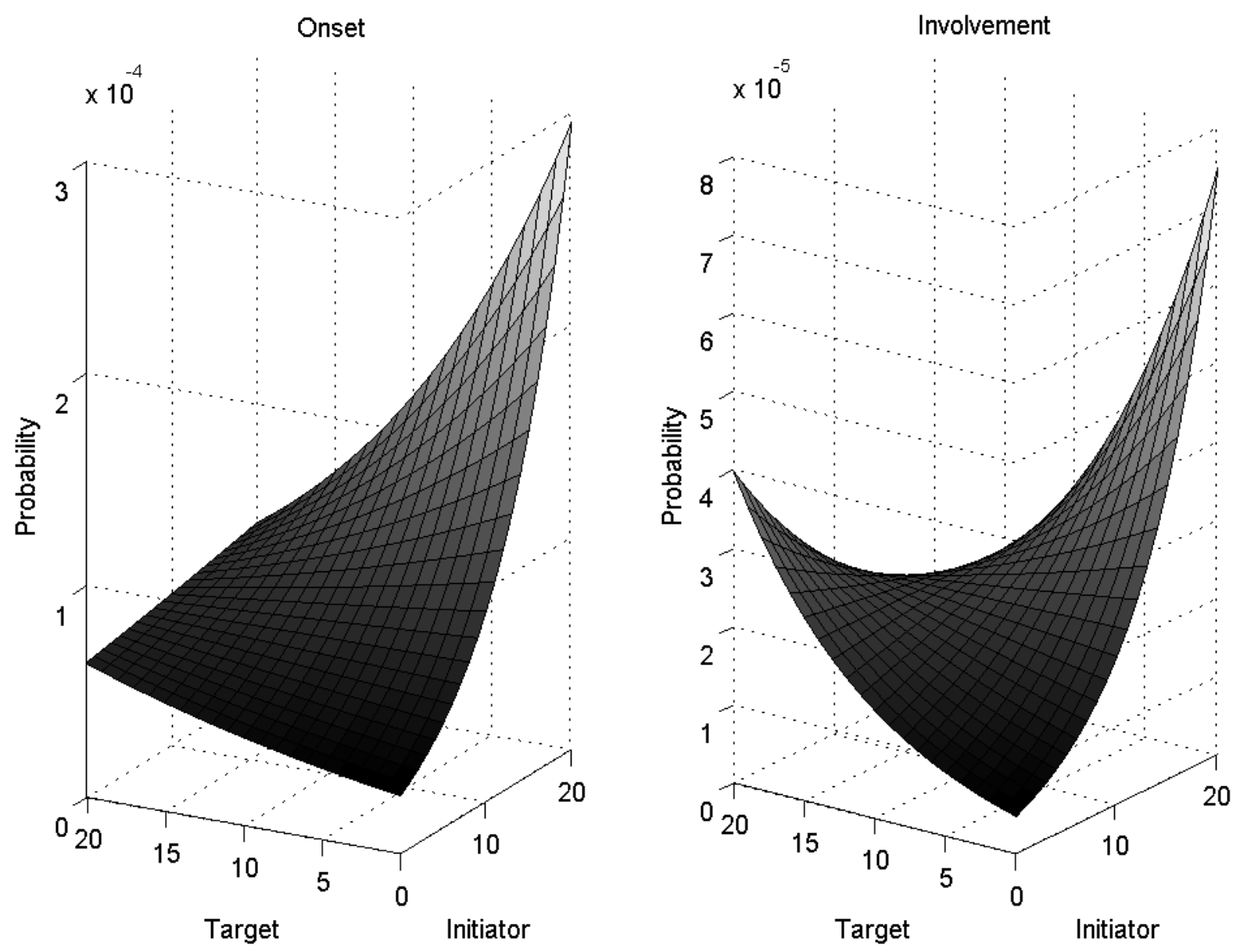